Limnological Review (2011) 11, 1: 7-13

DOI 10.2478/v10194-011-0022-4

\title{
Productivity of lakes varying in water mass dynamics
}

\author{
Jolanta Grochowska, Grzegorz Wiśniewski, Renata Tandyrak \\ University of Warmia and Mazury, Department of Environment Protection Engineering, Prawocheńskiego 1, 10-950 Olsztyn, Poland, \\ e-mail: jgroch@uwm.edu.pl
}

\begin{abstract}
The aim of the study was to reveal differences in the productivity of lakes varying distinctively in water mass dynamics, as shown by the examples of Lakes Track, Miodówko and Szeląg Wielki situated in the Olsztyńskie Lake District. The selected lakes are also characteristic for a high content of nutrients. The analysis of the obtained results has revealed that in the peak of the summer stagnation the productivity was the highest in the polymictic Lake Track. The content of chlorophyll $a$, which is a measure of primary production, in the Track waters reached the value of $123 \mathrm{mg} \mathrm{m}^{-3}$ whereas the water transparency measured as the visibility of a Secchi disc was below $0.6 \mathrm{~m}$. The lowest primary production in the summer was observed in the bradymictic Lake Miodówko. The transparency of water in this lake was nearly $3 \mathrm{~m}$ while the content of chlorophyll $a$ merely $1.7 \mathrm{mg} \mathrm{m}^{-3}$. Lake Szeląg Wielki, featuring the characteristics of a eumictic reservoir, in the peak of the summer period was noted for the average values of the analysed parameters ( $1.2 \mathrm{~m}$ water transparency, $40.3 \mathrm{mg} \mathrm{m}^{-3}$ chlorophyll $a$ ).
\end{abstract}

Key words: lake, primary production, water mass dynamics

\section{Introduction}

Productivity of lake can be expressed as a quantity of organic matter and energy produced by the aquatic organisms in a given ecosystem and time unit. Karlsson et al. (2009) share an opinion that productivity is the rate of biomass synthesis in a water reservoir. Nara et al. (2005) and Romero-Viana et al. (2009) observe the issue as being very complex, depending on the interactions between the physical factors, such as like temperature, light conditions, water mass dynamics or wind-induced turbulence, the chemical factors, such as like the content of nutrients in the euphotic zone, and the biological factors, e.g. the planktonic organisms. As early as 1960 Patalas argued that although the quantity of organic matter produced in a lake ecosystem during the vegetation period depends on the lake's richness in mineral salts, what is critical is the intensity of water mass circulation determined by the individual morphometric features of the lake, its surroundings, and wind power. In other words, in lakes with a comparable content of mineral compounds (particularly nitrogen and phosphorus) primary production should increase along with the growing intensity of the water (and nutrient) circulation.
The aim of the conducted study was to analyse the values of the organic matter indicators and the primary production parameters in three lakes varying in water mass dynamics, namely Lakes Track, Miodówko and Szeląg Wielki.

\section{Characteristics of the examined lakes}

Lakes Track, Szeląg Wielki and Miodówko are situated in the Olsztyńskie Lake District Mesoregion being a part of the Mazurian Lake District (Kondracki 2009). Lake Track, with the surface area of 52.8 ha and a max depth of $4 \mathrm{~m}$ (Tab. 1, Fig. 1), is situated in the north-eastern part of Olsztyn city, in the Łyna River catchment area (Jańczak et al. 1999). Having no permanent outflows, it periodically (during intensive precipitation) drains away on the north-eastern side. Lake Szelag Wielki, with a surface area of 599.0 ha and a max depth of $35.5 \mathrm{~m}$ (Tab. 1, Fig. 2), is situated in the Drwęca and Wisła Rivers catchment area and wholly within the Ostróda Commune's borders. Three small inflows feed the lake, two of them carrying water from the nearby Lakes Tabórz and Szeląg Mały. In the centre of the western shore the lake drains away with the Szeląg stream that splits up $500 \mathrm{~m}$ downstream and 
Table 1. Detailed morphometric data and lake parameters (after IRŚ, Olsztyn)

\begin{tabular}{|l|l|l|l|}
\hline Parameter & Track & Miodówko & Szeląg Wielki \\
\hline Water table surface area [ha] & 52.8 & 5.1 & 599.0 \\
\hline Maximum depth [m] & 4.0 & $18 ., 3$ & 35.5 \\
\hline Mean depth [m] & 2.1 & - & 13.5 \\
\hline Relative depth & 0.0052 & 0.0813 & 0.145 \\
\hline Depth index & 0.56 & - & 0.38 \\
\hline Volume [dam $\left.{ }^{3}\right]$ & 1123.0 & - & 81111.2 \\
\hline Maximum length [km] & 1.5 & 0.474 & 12.5 \\
\hline Maximum width [km] & 0.575 & 0.225 & 0.900 \\
\hline Elongation & $2 ., 6$ & 2.1 & 13.9 \\
\hline Shoreline length [km] & 4.65 & 1.25 & 28.00 \\
\hline Shoreline development & 1.86 & 1.56 & 3.23 \\
\hline
\end{tabular}

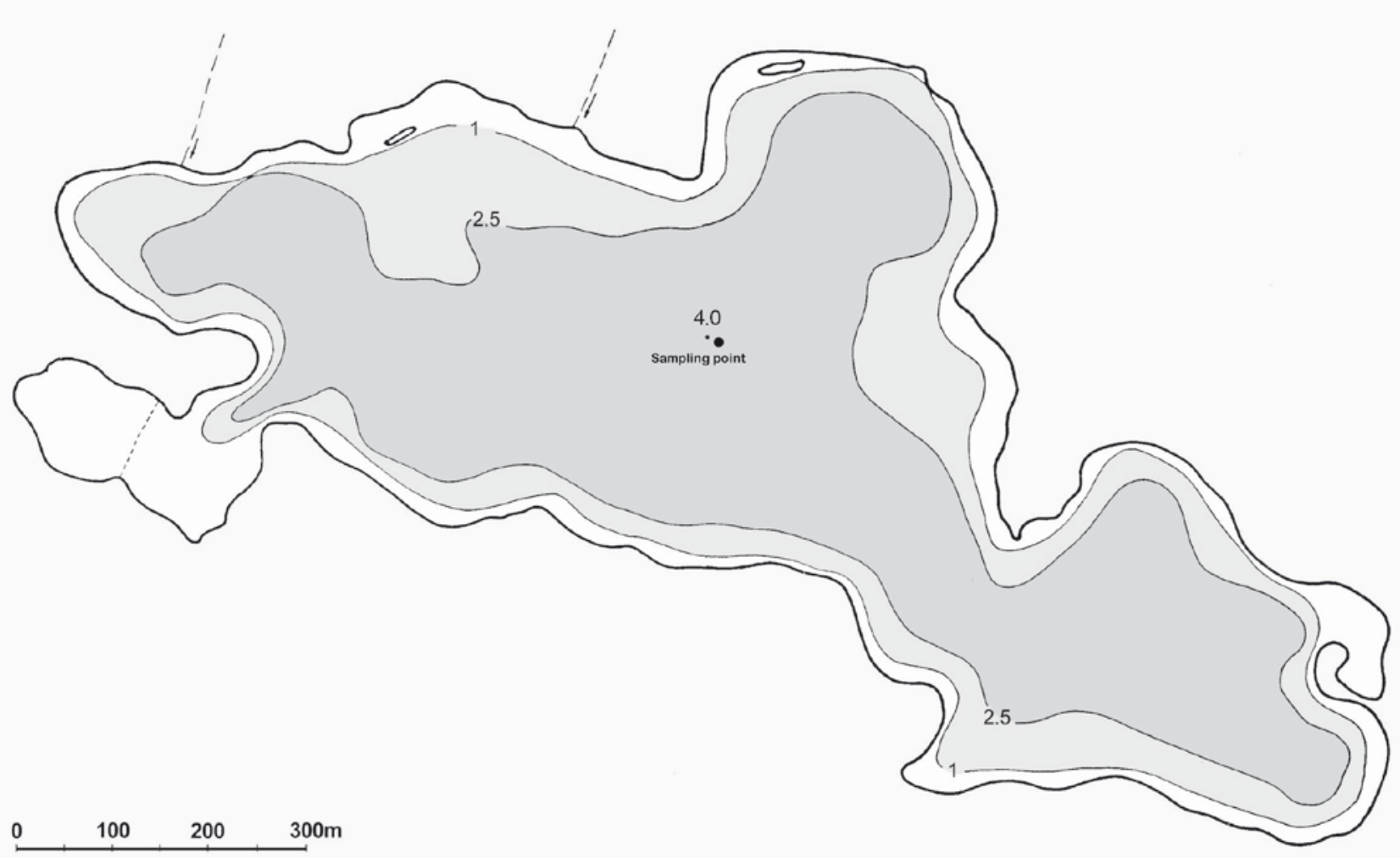

Fig. 1. Bathymetric plan of Track Lake

flows into Lake Pauzeńskie. Lake Miodówko lies in the Pasłęka River catchment area, Stawiguda Commune (Fig. 3). It is rather small (5.1 ha) but deep (18.3 m) (own measurements) (Tab. 1). The high relative depth of Lake Miodówko, 0.0813, indicates a hindered water mass dynamics. Miodówko is a flow-through reservoir. The southern shore is fed by a man-made stream connecting with Lake Pluszne. The outflow, flowing into the Pasłęka River, is situated in the north-eastern part.

\section{Methods}

The field and laboratory work was done four times: in April, June, August and November 2002 for Lake Track, and in April, June, August and November 2006 for Lakes Miodówko and Szeląg Wielki. On each lake one sampling site was determined with the help of bathymetric charts and GPS. They were set over the deepest sites of the lakes (Fig. 1-3). Water for the analyses was collected at the depths of $1 \mathrm{~m}$ un- 


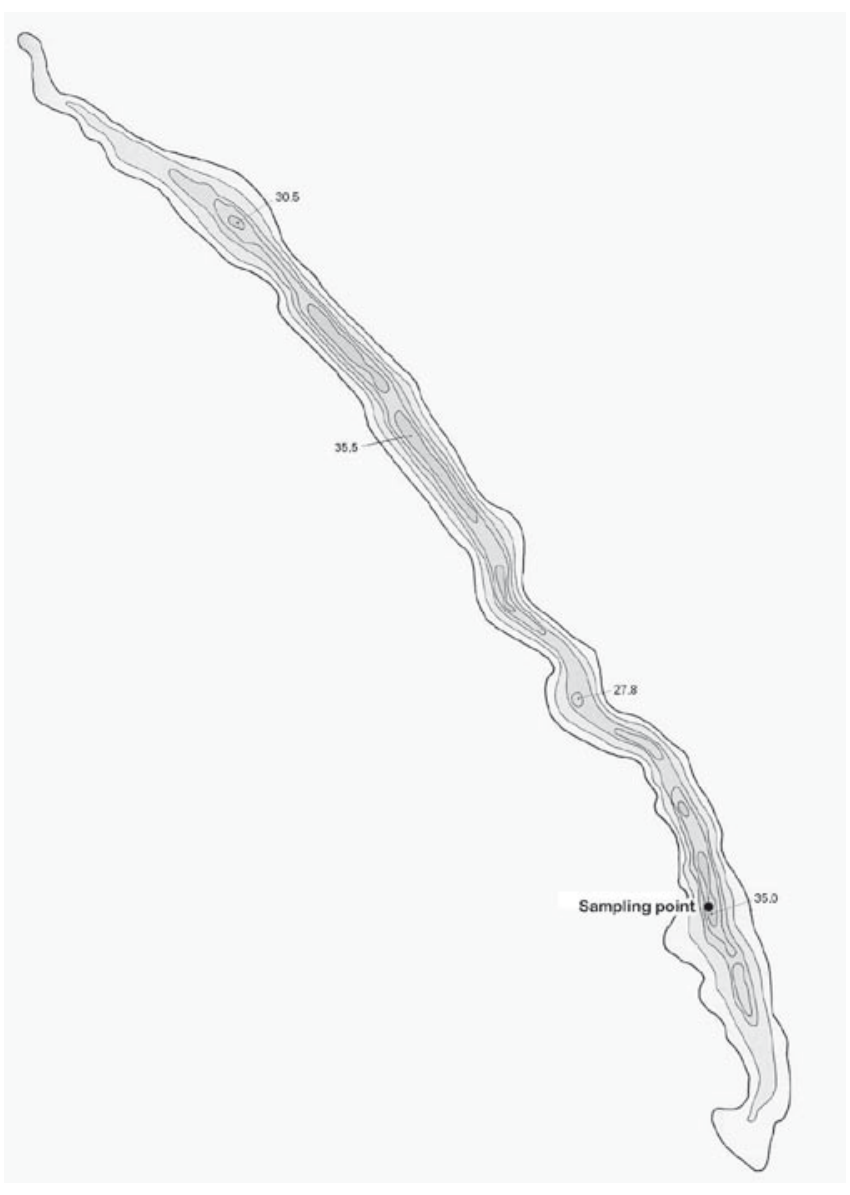

Fig. 2. Bathymetric plan of Szeląg Wielki Lake

der the water table and $1 \mathrm{~m}$ above the lake bottom, with a Ruttner apparatus with an inbuilt mercury thermometer $\left(0.2^{\circ} \mathrm{C}\right.$ accuracy). Additionally, temperature and dissolved oxygen (DO) measurements were made on each sampling site at every metre of the lake depth. DO was determined using the Winkler test. Mixis types of the examined lakes were determined based on the criteria given by Olszewski (1959) and their static properties in accordance with the division given by Patalas (1960). Productivity of the lakes was determined on the grounds of the conducted measurements of organic nitrogen, organic phosphorus, chlorophyll $a$, permanganate value $\left(\mathrm{BOD}_{5}\right)$, and water transparency. All examinations were conducted in accordance with the Methods given by Hermanowicz et al. (1999) and Standard Methods (1992).

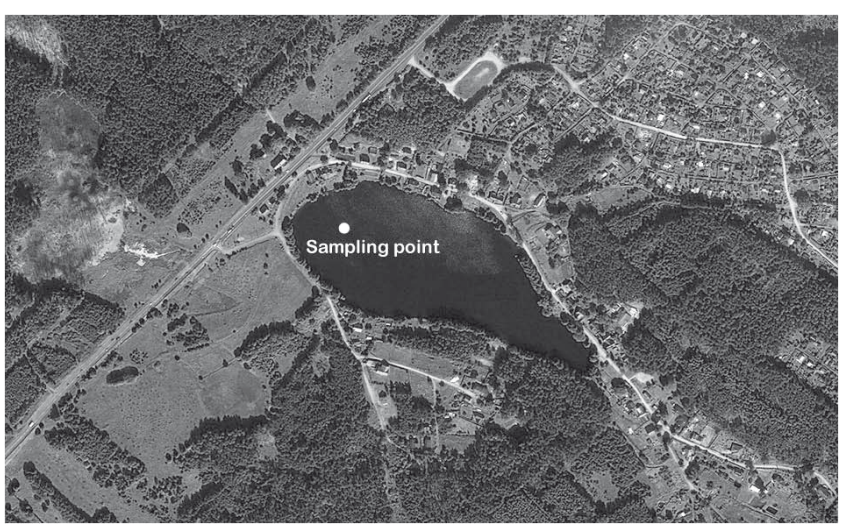

Fig. 3. Map of Miodówko Lake

\section{Results and discussion}

One of the factors that determine productivity of lakes is richness in mineral salts, particularly nitrogen and phosphorus (Kajak 1979). The higher the concentrations of those elements are, the higher the lake's trophic level is. Track, Szeląg Wielki and Miodówko are eutrophic lakes with a high production potential resulting from the markedly high concentrations of nutrients. The lakes are also characterised by comparable external loading; nitrogen and phosphorus loads per surface unit approximate $0.3 \mathrm{~g} \mathrm{P} \mathrm{m}^{-2} \mathrm{yr}^{-1}$ and $3.0 \mathrm{~g} \mathrm{~N} \mathrm{~m}^{-2} \mathrm{yr}^{-1}$.

The content of total phosphorus in Lake Track ranged from 0.123 to $0.750 \mathrm{mg} \mathrm{P} \mathrm{dm}^{-3}$, in Lake Szeląg Wielki from 0.180 to $0.410 \mathrm{mg} \mathrm{P} \mathrm{dm}^{-3}$, and in Lake Miodówko from 0.121 to $1.555 \mathrm{mg} \mathrm{P} \mathrm{dm}^{-3}$ (Tab. 2). The mean concentrations of total phosphorus in the surface water layers of Lakes Track and Miodówko in the growing season were comparable: 0.143 and 132 $\mathrm{mg} \mathrm{P} \mathrm{dm}{ }^{-3}$ respectively, whereas the value determined in Lake Szeląg Wielki was lower and equalled 0.223 $\mathrm{mg} \mathrm{P} \mathrm{dm}{ }^{-3}$ (Tab. 3). The examined lakes were also rich in nitrogen whose total quantity in Lake Track was $3.87 \mathrm{mg} \mathrm{N} \mathrm{dm}^{-3}$, in Lake Szeląg Wielki $2.43 \mathrm{mg} \mathrm{N} \mathrm{dm}^{-3}$, and in Lake Miodówko as much as $10.82 \mathrm{mg} \mathrm{N} \mathrm{dm}^{-3}$ (Tab. 2). On the other hand, the mean concentrations of total nitrogen in the surface water layers during the vegetation period were confined within the range of 1.78 to $3.22 \mathrm{mg} \mathrm{N} \mathrm{dm}^{-3}$ (Tab. 3).

Another important factor determining lake productivity is the intensity of water circulation. The examined lakes are different with regard to morphometric parameters and water mass dynamics. 
Table 2. Biogen content in studied lakes

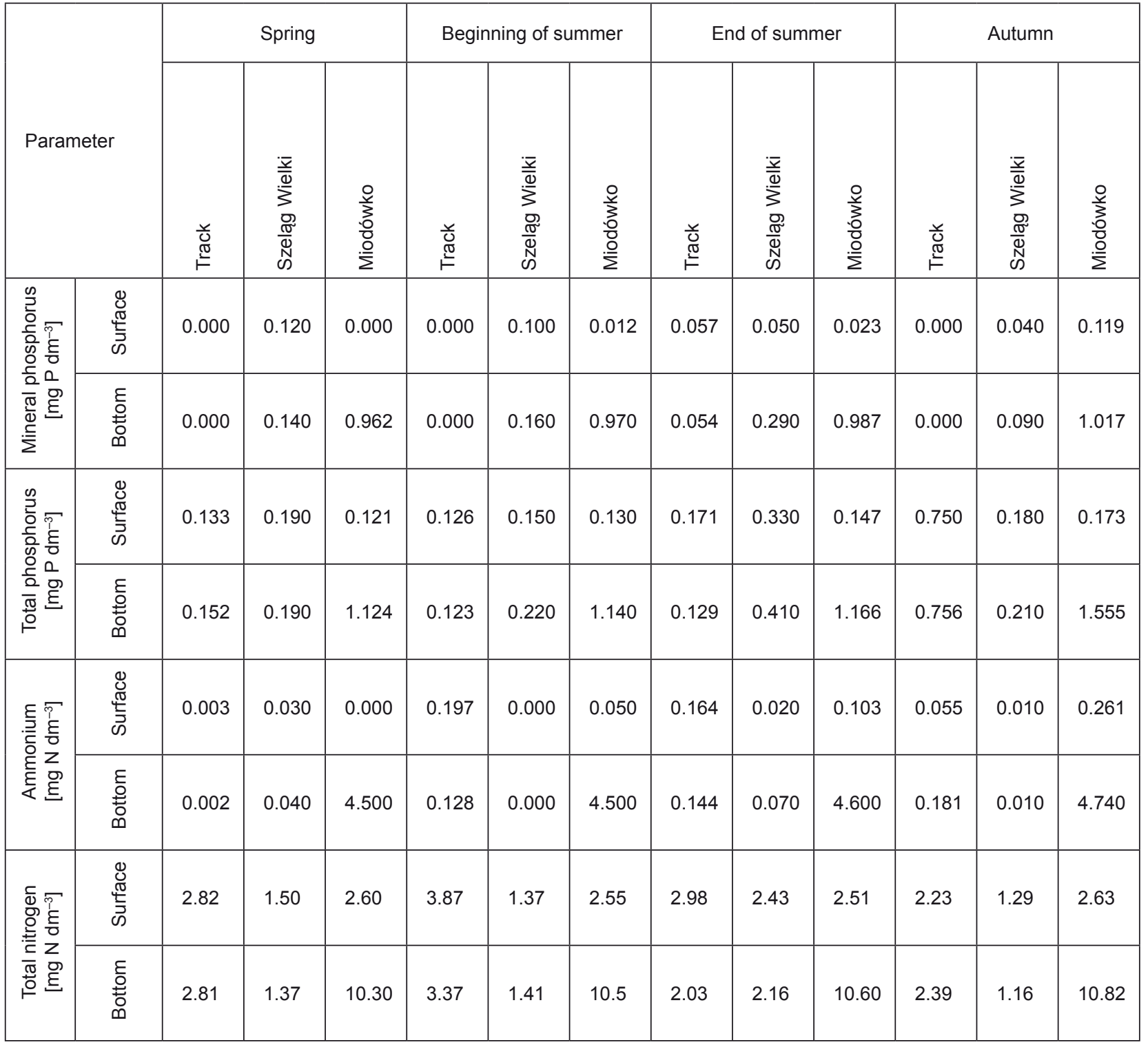

Table 3. Mean concentrations of total phosphorus, total nitrogen and organic matter in water of studied lakes in vegetation season

\begin{tabular}{|l|c|c|c|}
\hline Lake & $\begin{array}{c}\mathrm{TP} \\
{\left[\mathrm{mg} \mathrm{P} \mathrm{dm}^{-3}\right]}\end{array}$ & $\begin{array}{c}\mathrm{TN} \\
{\left[\mathrm{mg} \mathrm{N} \mathrm{dm}^{-3}\right]}\end{array}$ & $\begin{array}{c}\mathrm{BZT}_{5} \\
{\left[\mathrm{mg} \mathrm{O}_{2} \mathrm{dm}^{-3}\right]}\end{array}$ \\
\hline Track & 0.143 & 3.22 & 7.9 \\
\hline Szeląg Wielki & 0.223 & 1.78 & 2.9 \\
\hline Miodówko & 0.132 & 2.55 & 2.6 \\
\hline
\end{tabular}


Lake Track is an example of a polymictic reservoir, the determinants being mainly the relatively large surface area (52.8 ha) and the small depth (4.0 $\mathrm{m})$. Moreover, the relative depth (0.0052) is evidence of a small depression in the lake's bottom, which together with the flat and exposed shores creates favourable conditions for wind activity and thus for intensive circulation of the lake waters. From April to November 2002, the water temperature in the lake was practically identical across the whole water column, changing along with the ambient temperature (Fig. 4). The theoretical depth of water circulation (E) calculated for Lake Track with the Patalas equation (1960) is $4.5 \mathrm{~m}$ and exceeds the max depth by $0.5 \mathrm{~m}$. That is an indication of intensive water exchange across the surface-bottom interface and classifies the lake as 2 nd static grade.

Szeląg Wielki is a postglacial channel lake characterised by a large elongation (13.9). It spreads from northwest to southeast. The shores are varied, steep at some points, largely grown with forest. In the peak of the summer stagnation the lake was observed to develop a $7 \mathrm{~m}$ thick epilimnion, a metalimnion with the max gradient of $3.6^{\circ} \mathrm{C} \mathrm{m}^{-1}$, and a hypolimnion with the temperature near the bottom of $6.6^{\circ} \mathrm{C}$ (Fig. 4).

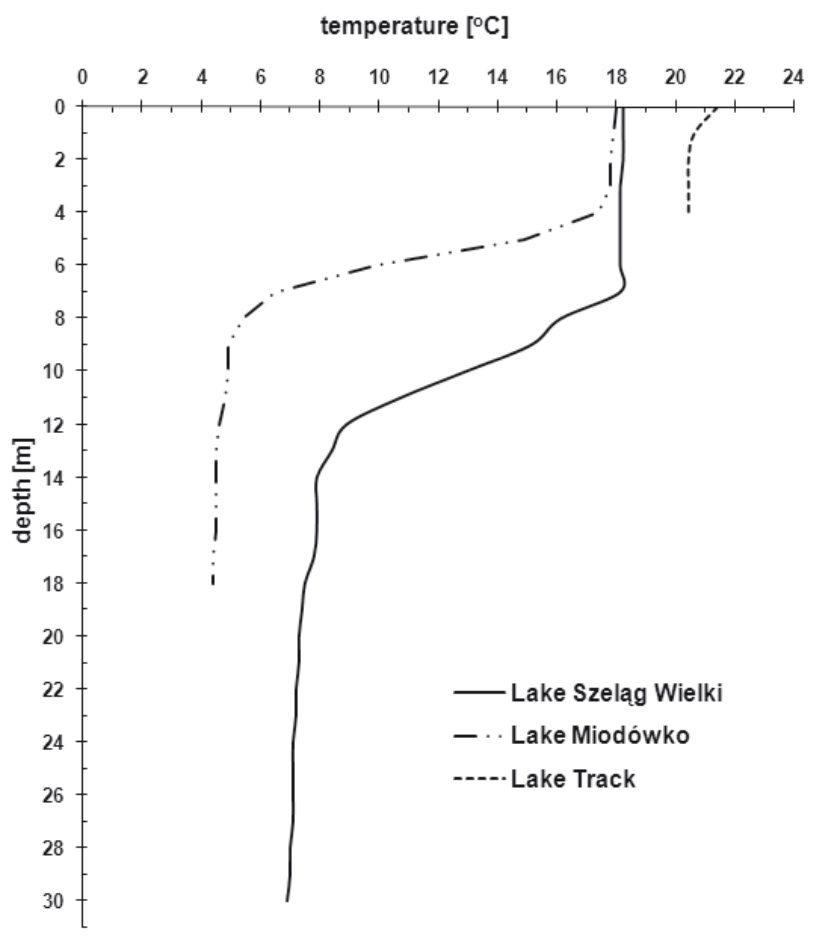

Fig. 4. Summer temperature profiles in studied lakes
Such a summer thermal setting, i.e., a moderately deep epilimnion and a moderately warm hypolimnion, as for the Mazurian climate conditions, indicates according to the criteria given by Olszewski (1959) a eumictic lake. The theoretical depth of epilimnion calculated for Lake Szelag Wielki from the Patalas equation (1960) is $11.4 \mathrm{~m}$ which is deeper by more than $4 \mathrm{~m}$ than the actual maximum thickness of that water layer. The ratio between the theoretical epilimnion depth and the max lake depth, characterising the intensity of water exchange between the hypo- and epilimnion, is 0.3 . According to the classification given by Patalas (1960) the value indicates a rather intensive water exchange between those layers and classifies the lake as 3rd static grade.

Lake Miodówko is small (5.1 ha) but deep (18.3 $\mathrm{m})$. It is located in a deep land depression and surrounded by a forest and some housing development. Wind access to the lake is hindered. In the peak of the summer stagnation the temperature setting followed the pattern: the epilimnion was $4 \mathrm{~m}$ thick, the metalimnion had a max gradient of $4.4^{\circ} \mathrm{C} \mathrm{m}^{-1}$, the hypolimnion temperature near the bottom was $4.4^{\circ} \mathrm{C}$ (Fig. 4). The temperature gradient across the whole water column was $13.6^{\circ} \mathrm{C}$ which indicated a high stability of the summer stratification (Patalas 1960). Taking into account the classification of lakes given by Olszewski (1959), based on the epilimnion depth and the hypolimnion temperature, Lake Miodówko can be classified as bradymictic. Olszewski et al. (1978) examined the lake in the 1960s and classified the lake in the same way. The theoretical depth of water circulation (according to Patalas, 1960) is $2.6 \mathrm{~m}$, which is $1.4 \mathrm{~m}$ less than the actual thickness of that layer. The ratio between the theoretical depth of water circulation and the actual max depth of the lake is 0.14 . With the actual thickness of the epilimnion and the hypolimnion temperature taken additionally into account, the lake falls in the class of 5th static grade (Patalas 1960).

Taking into consideration that the selected lakes are rather similar with regard to their productivity potential, it may be assumed that the highest productivity should be observed in Lake Track featuring a high water dynamics. Nędzarek and Tórz (2009) emphasise that intensive water circulation creates favourable conditions in a lake for the maximum nutrient turnover within the production zone and for the growth of organic matter production.

Among the parameters describing organic compound content in the water, Tandyrak and Parszuto 
(2006) point out organic forms of phosphorus and nitrogen. The content of organic phosphorus in the examined surface water layers in the vegetation period oscillated between 0.05 and $0.280 \mathrm{mg} \mathrm{P} \mathrm{dm}^{-3}$. The lowest concentrations of organic phosphorus were observed for most of the period in Lake Szeląg Wielki. They increased at the end of August which should be connected with the wash out of matter from the catchment area (heavy rains were noted then) rather than with the production processes. In the other lakes, the concentrations of organic phosphorus were comparable (Fig. 5). The values of organic nitrogen in the upper water layers of the examined lakes were confined within the range from 1.12 to $3.55 \mathrm{mg} \mathrm{N} \mathrm{dm}^{-3}$ (Fig. 6). The maximum values were observed in the polymictic Lake Track whereas the lowest in Szeląg Wielki, indicating average water mixis conditions. The total quantity of easily biodegradable organic matter produced in a lake ecosystem can be determined with a $\mathrm{BOD}_{5}$ index. As the studies conducted in the vegetation period have shown, in the surface water layers of the examined lakes concentrations of that kind of organic matter differed considerably (Tab. 3). The highest values ( $7.5 \mathrm{mg} \mathrm{O}_{2} \mathrm{dm}^{-3}$ on average) were determined in the polymictic Lake Track whereas the lowest in the bradymictic Lake Miodówko $\left(2.6 \mathrm{mg} \mathrm{O}_{2} \mathrm{dm}^{-3}\right)$. In Szelarg Wielki, the mean $\mathrm{BOD}_{5}$ in the growing season equalled $2.9 \mathrm{mg} \mathrm{O}_{2} \mathrm{dm}^{-3}$.

The following group of parameters is the indices determining the size of primary production, i.e., chlorophyll $a$ and visibility of a Secchi disc (Håkanson et al. 2005). Sun rays' penetration in water depends, among other things, on the particles suspended in the water, including the amount of phytoplankton cells. In Lake Miodówko, with rather unfavourable conditions for water circulation and multiple utilisation of nutrients in the production, the concentrations of chlorophyll $a$ were the lowest: $1.7-5.5 \mathrm{mg} \mathrm{m}^{-3}$ (Fig. 7). The Secchi disc visibility in this lake ranged from 2.5 to $2.8 \mathrm{~m}$ and remained practically unchanged during the whole vegetation period (Fig. 8). In contrast, the quantities of chlorophyll $a$ determined in the polymictic Lake Track were very high, i.e., from 37.4 to $123.5 \mathrm{mg} \mathrm{m}^{-3}$ (Fig. 7) and accompanied by a very low water transparency of less than $0.8 \mathrm{~m}$ for the whole production period (Fig. 8). In Lake Szeląg Wielki, characterised by average water mixis conditions, the chlorophyll $a$ values were confined within the range from 10.8 to $40.3 \mathrm{mg} \mathrm{m}^{-3}$ and the Secchi disc visibility varied between 1.2 and $3.6 \mathrm{~m}$ (Fig. 7, 8).

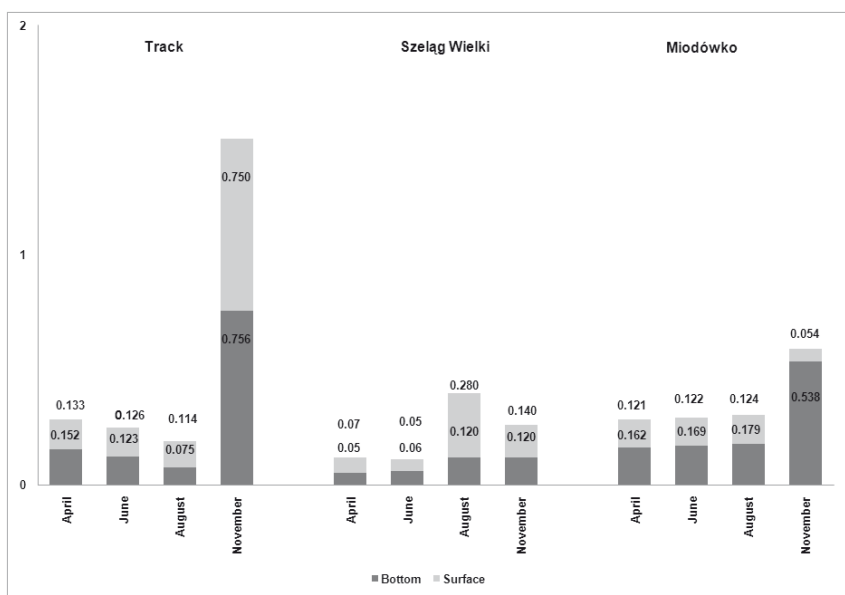

Fig. 5. Content of organic phosphorus in studied lakes [mg $\left.\mathrm{P} \mathrm{dm}^{-3}\right]$

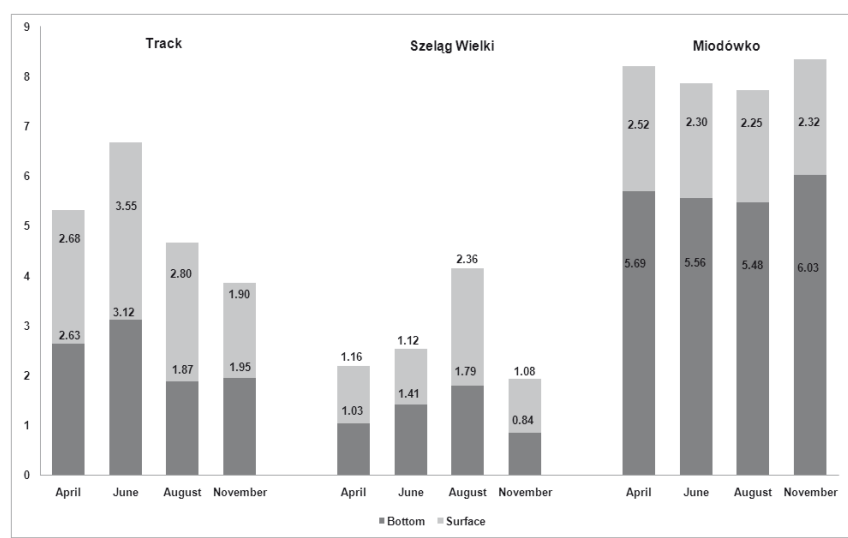

Fig. 6. Content of organic nitrogen in studied lakes [mg $\mathrm{N} \mathrm{dm}^{-3}$ ]

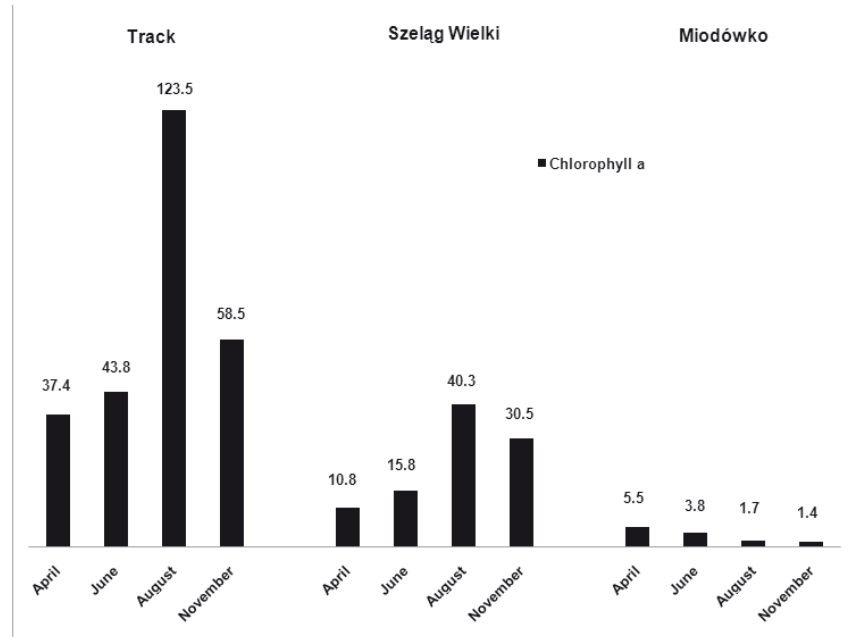

Fig. 7. Changes of chlorophyll $a$ contents $\left[\mathrm{mg} \mathrm{m}^{-3}\right]$ in water of studied lakes 


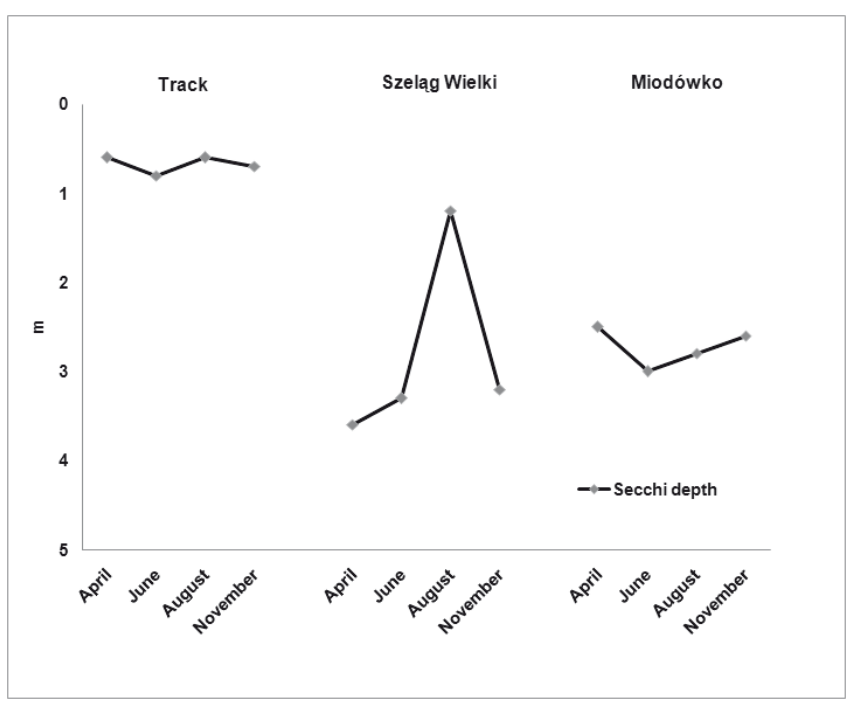

Fig. 8. Changes of Secchi disc visibility in studied lakes

\section{Summary}

The study has confirmed that water richness in mineral salts has an effect on the production processes in a lake. However, in the vegetation period it is the water mass dynamics that has the critical impact. The higher the water mass dynamics, the higher the values of the indices determining the size of primary production and the organic matter content. The phenomenon is a resultant of the multiple consumption of the available nutritive resources through intensive water mixis.

\section{References}

Håkanson L., Blenckner T., Bryhn A.C., Hellström S.S., 2005, The influence of calcium on the chlorophyll-phosphorus relationship and lake Secchi depths, Hydrobiologia 537: 111-123.

Hermanowicz W., Dojlido J., Dożańska W., Koziorowski B., Zerbe J., 1999, Fizyczno- chemiczne badanie wody i ścieków (Physico-chemical investigation of water and sludge), Arkady, Warszawa, p.627 (in Polish).

Jańczak J., Brodzińska B., Kowalik A., Sziwa R., 1999, Atlas jezior Polski, tom 3 (Atlas of Polish lakes, vol. 3), Bogucki Wyd. Nauk., Poznań, p. 240 (in Polish).
Kajak Z., 1979, Eutrofizacja jezior (Lake eutrophication), PWN, Warszawa, p. 233 (in Polish).

Karlsson J., Byström P., Ask J., Persson L., Jansson M., 2009, Light limitation of nutrient poor lake ecosystems, Nature 460: 506-509.

Kondracki J., 2009, Geografia regionalna Polski (Regional geography of Poland), Wyd. Nauk. PWN, p. 468 (In Polish).

Nara F., Tani Y., Soma Y., Soma M., Naraoka H., Watanabe T., Horiuchi K., Kawai T., Oda T., Nakamura T., 2005, Response of phytoplankton productivity to climate change recorded by sedimentary photosynthetic pigments in Lake Hovsgol (Mongolia) for the last 23,000 years, Quat. Int. 136: 71-81.

Nędzarek A., Tórz A., 2009, The primary production of Tertiary estuary (Dąbie Lake, Poland), Limnol. Rev. 9: 17-26.

Olszewski P., 1959, Stopnie nasilenia wpływu wiatru na jeziora (Graduation in the intensity of the wind effects on lakes), Zesz. Nauk. WSR Olszt. 4: 111-132 (in Polish, English summary).

Olszewski P., Tadajewski A., Lossow K., Więcławski F., 1978, Wstępna charakterystyka limnologiczna niektórych jezior Pojezierza Mazurskiego. Część II) (Preliminary limnological characteristics of some lakes in the Mazurian Lakeland. Part II), Zesz. Nauk. ART Olszt. 7, p. 80 (in Polish, English summary).

Patalas K., 1960, Mieszanie wody jako czynnik określający intensywność krążenia materii w różnych morfologicznie jeziorach okolic Węgorzewa (Mixing of water as the factor defining intensity of food materials circulation in morphologically different lakes of Węgorzewo district), Rocz. Nauk Roln. 77(B)1: 223-242 (in Polish, English summary).

Romero-Viana L., Keely B.J., Camacho A., Vicente E., 2010, Primary production in Lake La Cruz (Spain) over the last four centuries: reconstruction based on sedimentary signal of photosynthetic pigments, J. Paleolimnol. 43: 771-786.

Standard Methods for Examination of Water and Wastewater, 1992, Am. Publ. Health Ass., Washington, p. 2050.

Tandyrak R., Parszuto K., 2006, Multi-Year Investigation of Organic Substances in the Waters of Lake Starodworskie, Arch. Environ. Prot. 32(3): 29-40.

Tórz A., Kubiak J., 2006, Influence of the selected hydrochemical factors upon the nitrogen -phosphorus ratio and factors restraining primary production in coastal lakes: Koprowo, Liwia, Łuża and Resko Przymorskie, Acta Sci. Pol., Piscaria 5(2): 83-98. 